\title{
GETTING IT WRONG IN ASSYRIA: SOME BRACELETS FROM NIMRUD
}

\author{
By DOMINIQUE COLLON
}

In 1989 Muzahem Mahmud Hussein found the second of four rich tombs in the harem section of the NorthWest Palace of Ashurnasirpal II at Nimrud. The tomb contained the burials of Yaba, queen of Tiglathpileser III, and of Atalia, queen of Sargon II, and the tomb can therefore be dated to the last decades of the eighth century BC. This paper concerns three pairs of bracelets from Tomb II, and focuses in particular on the strange iconography of one of the pairs.

David is one of my oldest and dearest friends. We met at the Institute of Archaeology in 1962 where we were both students. Our common interest in Anatolia meant that subsequently we frequently met in Turkey, and we still do. We took part in the same excavations at Kayalidere in Urartu (see this volume), and in a conference on Urartu involving an epic journey to Van that had us rather uncomfortably sharing the co-driver's bed behind the back seats of a bus during the day-time journey from Yozgat to Erzerum! More recently we visited the Hittite equivalent of a Hittite garden gnome-centre at Yesemek.

In the 1960s, as a Belgian national I was a "fiendish foreigner", and although I worked as a special assistant in the British Museum for years, I was only able to get a "proper" job years later after the law was changed. David fed me articles that needed typing (he still does not type!), and the brackets, diacritics, double and single underlining, and so on, needed for the transliteration of Luwian inscriptions in the days before computers, taxed my limited typing skills to the utmost, and I'm sure he always overpaid me. This was a task I resumed when I came back from New York in 1975 after obtaining my PhD there. David also trained me up to edit the journal Iraq so that I was able to step into Donald Wiseman's shoes as co-editor with David in 1979. I was still without a "proper" job and it was only years later that I discovered that David had negotiated a pay-rise for us as editors that he had not claimed for himself. David retired after being editor for 25 years and Andrew George and I have worked in tandem since then. The present volume of Iraq will be my thirty-second and my last as editor. I wanted to be able to work on the present volume and honour a distinguished and generous colleague and a great friend. Thank you David.

\section{Introduction}

In 1989, while he was excavating at Nimrud, Muzahem Mahmud Hussein found the second of four rich tombs in the harem section of the North-West Palace of Ashurnasirpal II (883-859 BC) at Nimrud, beneath the floor of Room 49. Inscriptions tell us that the tomb contained the burials of Yaba, queen of Tiglath-pileser III (744-727 BC), and of Atalia, queen of Sargon II (721-705 $\mathrm{BC}$ ), who had reused the mirror that formed the lid of a cosmetics container inscribed with the name of Banitu, queen of Shalmaneser V (726-722 BC). ${ }^{1}$ The tomb can therefore be dated to the last two decades of the eighth century вС. This paper concerns three pairs of bracelets from Tomb II, found among the $14 \mathrm{~kg}$ of gold objects that the tomb contained. I will focus in particular on the strange iconography of one of the pairs.

Ackowledgements: The photographs of the Nimrud bracelets (Figs. $1-3$ and $14 a$ ) are edited versions of those taken by Donny George who very kindly supplied them to me. Photographs for Figs. 4-8, 10,11, 12b and $13 a$, and the drawing for Fig. $14 b$ are by the author. Abbreviations: $\mathrm{BM}=$ London, British Museum; IM = Iraq Museum regis- tration numbers. I should like to thank Julian Reade for his helpful comments.

${ }^{1}$ The names Yaba and Atalia are both Levantine, and Dalley (2008, p. 171) has suggested that Banitu was the Assyrian name later adopted by Yaba. For the inscriptions, see Al-Rawi 2008, Texts Nos. 1, 18-24. 
The bracelets were published both in a catalogue by Muzahem Mahmud Hussein and Amer Suleiman, ${ }^{2}$ and also by Muayad Said Basim Damerji. ${ }^{3}$ The bracelets, together with the other objects from the tombs, were almost immediately shut away in a bank vault. This had the advantage of protecting them from looting during the First Gulf War in 1991, and at the time of the ransacking of the Iraq Museum in Baghdad in 2003. It means, however, that they have been unavailable for the study of details of manufacture and design, and the identification of the materials used. Furthermore, the colour of the objects and their inlays vary considerably in the published illustrations, particularly as the negatives of Donny George's excellent photographs were adversely affected during processing for the catalogue, and this resulted in huge distortion of the colours.

Pair 1 (Cat. Pic. 30).

IM 105706 and 105707.

Weight $500.8 \mathrm{gm}$. and $551.3 \mathrm{gm}$.

Bracelet diameter $7 \mathrm{~cm}$; Face diameter $6.5 \mathrm{~cm}$.

The front, or face, of each bracelet is a slightly convex disc with a design radiating from a brown-and-white agate eyestone. The decoration of the disc is in gold against an inlaid background, but much of this inlay is now missing. Three concentric gold bands of increasing width are set with rectangular pieces of inlay. The narrowest band runs round the central eyestone, and the second forms the upper edge of a band of overlapping pointed "arches" containing brown and white agate inlay. The third forms the edge of the disc, framing a broad band with eight pairs of winged figures kneeling on one knee, holding a cone in the raised hand furthest from the viewer and a bucket in the lowered hand closest to the viewer, and each pair flanks a rosette-topped tree, with another similar tree behind. The disc is attached to a broad gold band that is hinged and fastened by a pin. The hinge consists of eighteen cells arranged in six rows, containing inlay said to be of semi-precious stones. This is followed, on the photograph, by two groups of four brownand-white agate cylinders set above each other, separated by a group of four gold cylinders, but it is not clear whether this sequence of agate and gold cylinders repeats itself around the bracelet.

Pair 2 (Cat. Pic. 32; Damerji Abb. 30 bottom; Oates and Oates 2001, Pl. 6a; Curtis et al. 2008, Pl. IIa).

IM 105702 and 105703.

Weight $826.9 \mathrm{gm}$. and $811.5 \mathrm{gm}$.

No dimensions are given, but note that Pair 2 is far heavier than Pair 1.

The decoration of the face of the discs of this pair is the same as that of Pair 1, but the rosettes of the trees are larger, and the disc is attached to a broad band edged with brown-and-white agate beads (several missing) alternating with short gold cylinders. The vertical end nearest the disc is probably hinged, and consists of about six inlaid motifs resembling stepped crenellations. There is then a vertical framed band of four gold rosettes with turquoise centres abutting on two horizontal framed bands containing 21 rosettes each, which, in turn, frame a horizontal band of ten brown-and-white agate eyestones. According to the description accompanying Cat. Pic. 32, the two bracelets of Pair 2 are differentiated in that "on one of them is the drawing of a lion, on the other a pair of lions."

Pair 3 (Cat. Pic. 31; Damerji, Abb. 30 top; Curtis et al. 2008, Pl. IIb-d).

IM 105704 and 105705.

Weight $714 \mathrm{gm}$. and $696.6 \mathrm{gm}$.

Diameter $7.5 \mathrm{~cm}$; Face diameter $5.3 \mathrm{~cm}$.

The two published photographs show the front and back of two different bracelets, as can easily be seen if one compares the position of the missing inlay of the rosettes on the main disc: the

\footnotetext{
${ }^{2}$ Hussein and Suleiman 1999 (hereafter referred to as Cat. or Catalogue), Pics. 30-2. The authors are to be congratulated for producing such an informative catalogue in the very short time available.

${ }^{3}$ Damerji 1999 (hereinafter referred to as Damerji),
}

Abb. 30 , and p. $47, \mathrm{Abb} .23$ - a useful photograph as it shows three bracelets from Pairs 1 and 2 in the context of other objects from the tomb, thus illustrating the relative sizes of the objects. 


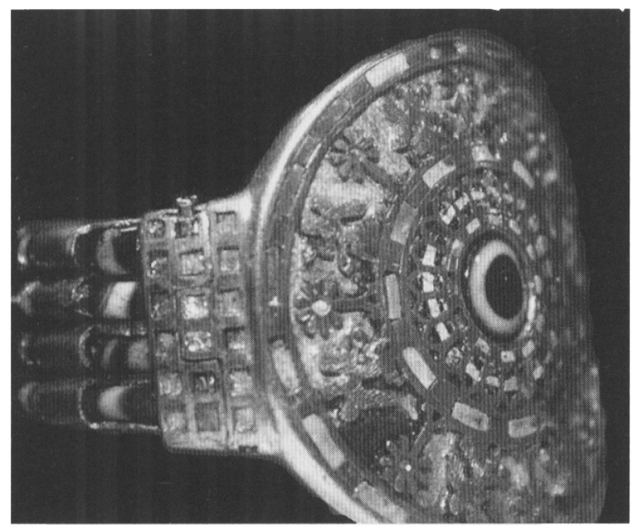

Fig. 1 Nimrud Tomb 2 bracelet from Pair 1.
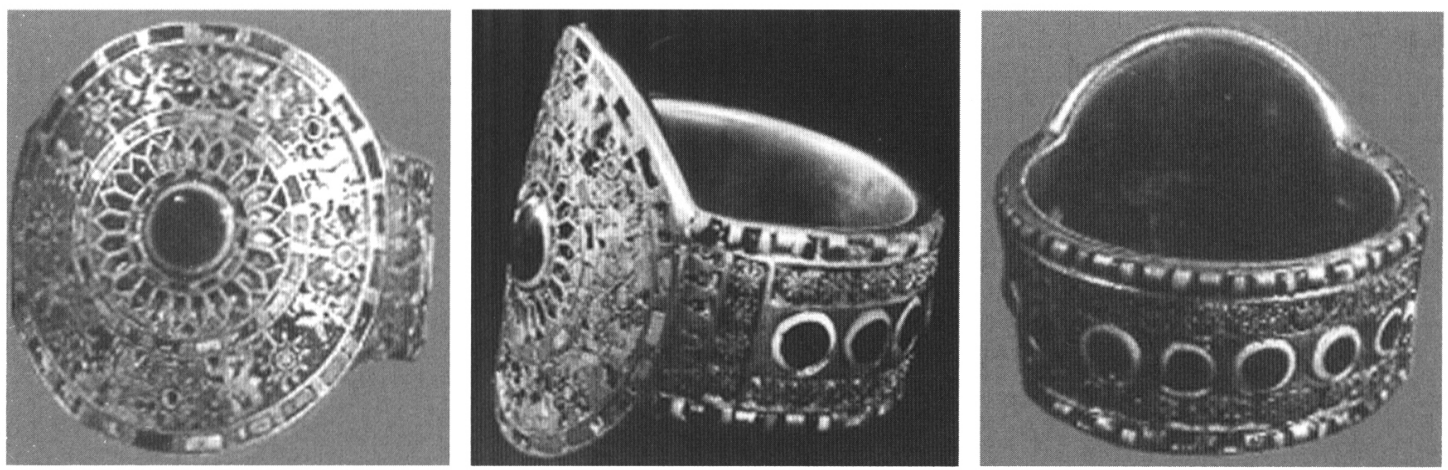

Fig. $2 a-c \quad$ Nimrud Tomb 2 bracelets, Pair 2 .
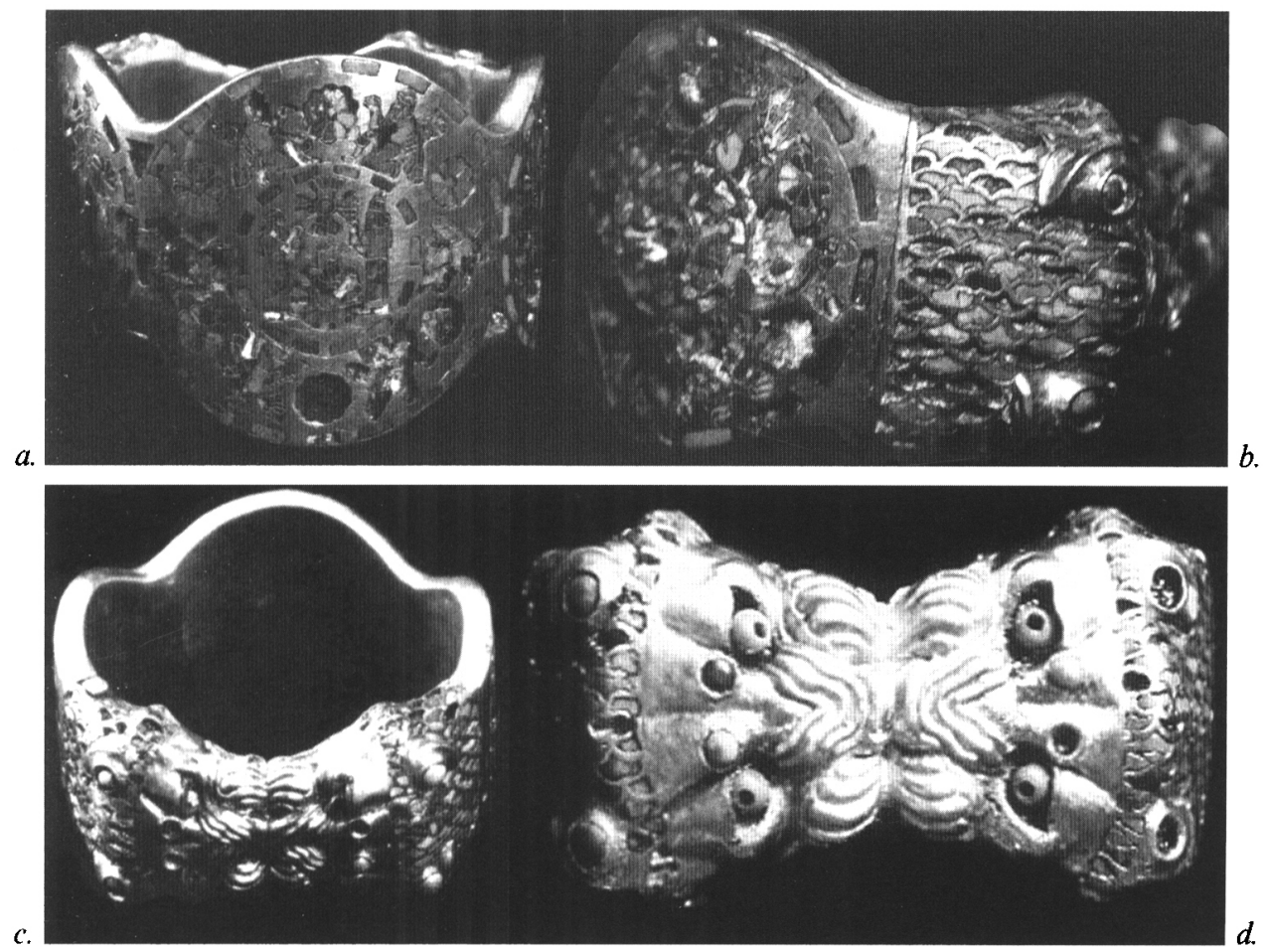

Fig. $3 a-d$ Nimrud Tomb 2 bracelets, Pair 3. 
inlay of the top rosette is missing on the Catalogue bracelet and that of the bottom rosette on the Damerji one; furthermore, there are inlaid eyes for the lions on the photograph in the Catalogue, that are missing on the photograph in Damerji. Each bracelet consists of one large disc flanked by two lower ones, with a hinged section at the back formed by the heads of two lions, muzzleto-muzzle. All parts of the bracelets are inlaid with semi-precious stones and possibly also with faience, glass or enamel. The discs on the side are said to be "similar to the face of the bracelet in shape and decoration", but from the single angled photograph available it seems that the motif is indeed the same round the outer concentric band of all three discs and is very close to that on the discs of Pairs 1 and 2. However, the major difference between decoration of this third pair and that of Pairs 1 and 2 is that here it is the motif that is recessed and inlaid, and the background is gold. The pieces of inlay seem to be bordered by very thin gold strips and are said to be of "precious stones". The photographs in Damerji (Abb. 30 top) show a predominance of yellowishgreen inlay which, elsewhere, looks more like turquoise - a material rarely attested in Mesopotamia. However, where flesh is depicted, the inlays are a brilliant white, perhaps ivory, faience, glass or enamel.

Here too, therefore, the motif consists of a broad band with pairs of winged figures kneeling on one knee and holding a cone in the raised hand furthest from the viewer and a bucket in the lowered hand closest to the viewer, but in this case each pair flanks a large inlaid ten-petalled rosette, and not a tree, with another similar rosette behind them. Furthermore, there are only three pairs of figures and only six rosettes, as opposed to four pairs of figures and eight rosettes on Pairs 1 and 2. The motif at the centre of the side discs (see Fig. $3 b$ ) is not clear, but is probably a flower surrounded by ornamental leaves that perhaps have upward-curving tips. What is certain is that it in no way resembles the much larger and more complex motif on the central disc. This motif will be discussed in detail below.

The section consisting of the lions' heads is hinged and fastened by a pin. The heads are muzzleto-muzzle, with the muzzles heavily moulded into creases. The inlay probably consisted of turquoises, with large pierced beads for the eyes, and pairs of smaller beads between and just above the level of the eyes, and further beads in special sockets in the mane where the ears should be. The mane, however, consists of sockets for inlay that are mostly shaped like small spread wings and are filled with turquoise or turquoise-coloured inlay. As a result, the mane looks very much like a snake's skin, and it may be that this is what was intended. ${ }^{4}$ However, leaf-shaped sockets occur in the manes of two embracing lions on an ivory bowl of the North Syrian "flame and frond" style-group, found in Well AJ at Nimrud. ${ }^{5}$ Because related ivories were found at Hasanlu in north-western Iran, this style-group must have predated the destruction of that site, originally dated to the end of the ninth century $\mathrm{BC}$. However, destruction in the reign of Sargon II (726-722 BC) has since plausibly been suggested (Medvedskaya 1988).

\section{Typology of the bracelets}

\section{Discussion}

The radiating decoration of the bracelets recalls that depicted on the bracelets of Assyrian kings, which are therefore referred to here as "Royal bracelets" although they are also occasionally worn by queens (see below), courtiers and high officials, ${ }^{6}$ some gateway lamassu figures, ${ }^{7}$ minor deities and genii (e.g. Fig. $4 b-c$ ), and other apotropaic figures. The diameters of the three Nimrud pairs would fit a man's wrist. On early ninth-century BC Assyrian reliefs and stelae these "Royal bracelets" are depicted with a radiating design consisting of a simplified rosette, generally with many pointed petals; later they are depicted as a central disc rosette surrounded by a concentric outer row of petals. Since rosettes seem to have been used in the Middle East from early times as a symbol of fertility and protection, this was probably the underlying meaning of these bracelets, which protected a vulnerable point — a main artery — and reflected the role of the king as

\footnotetext{
${ }^{4} \mathrm{Cf}$. the handle of the jug from Nimrud Tomb 3, illustrated in Damerji, Abb. 51, and Curtis et al. 2008, Pl. VII.

${ }^{5}$ Herrmann 2009, No. 237, pp. 91-5, 188-9, Fig. 38, Pls. 56-8, $\mathrm{N}$ and $\mathrm{O}$.

${ }^{6}$ E.g. Russell 2008, Fig. 23-e from Room G; Paley and
}

Sobolewski 1987, Pl. 2, S-2 and S-4 from Room S, and under later kings (see below).

${ }_{7}^{7}$ Paley and Sobolewski 1992, Figs. 4, 5 and PI. I, respectively entrances $D, E$. 

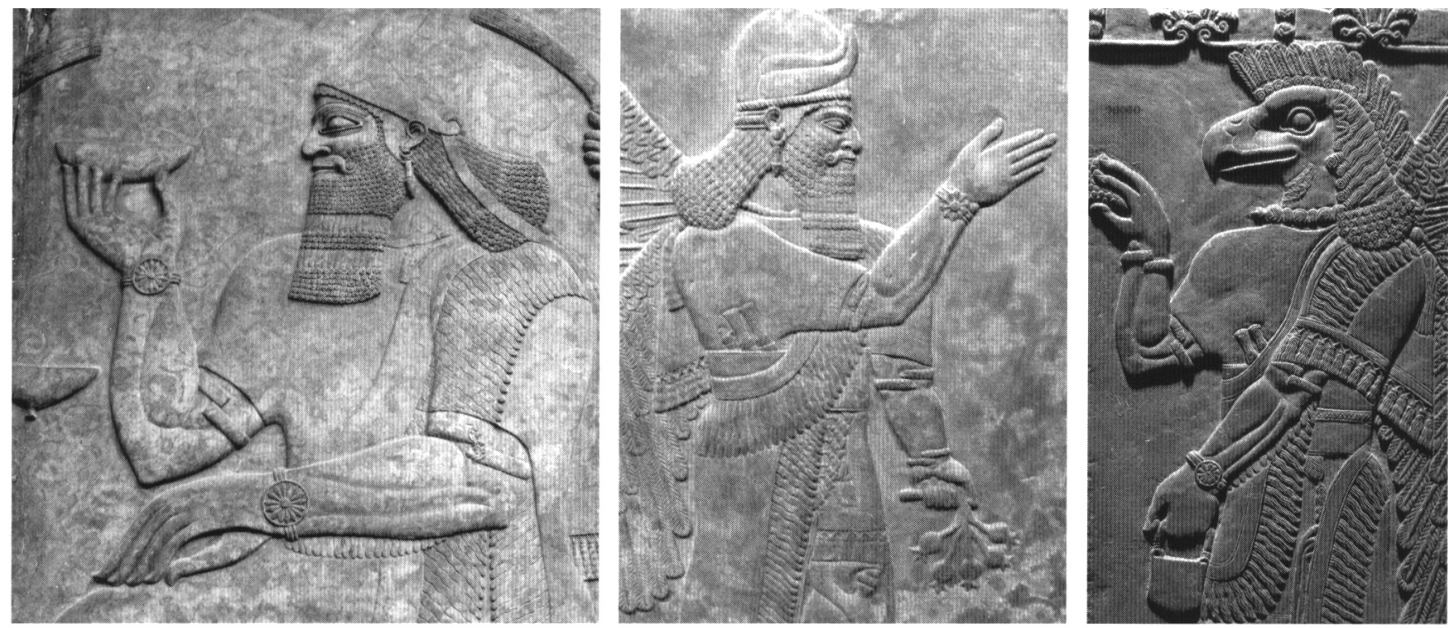

Fig. 4 Details of Ashurnasirpal II reliefs from Nimrud, c. 865-860 BC. a. North-West Palace, Room G: The king (BM 124565).

b. North-West Palace, Room Z: A minor deity (BM 118870).

c. Temple of Ninurta: An apotropaic genie (BM 98060).

protector of the realm. They are almost always depicted on each wrist. ${ }^{8}$ Indeed, these Nimrud examples were found in pairs, they were heavy and they were valuable, weighing between 500 to over $800 \mathrm{gm}$, most of which was gold. The fact that there are lions incised on the interior faces of both bracelets of Pair 2 would suggest that they were the property of the king or of the palace. ${ }^{9}$

The wearing of bracelets and armlets seems to have been a typically Neo-Assyrian custom, and the "Royal bracelet" was a symbol of Assyrian kingship. No bracelets are shown on representations of contemporary Babylonian and Iranian rulers. ${ }^{10}$ Syria is a partial exception, with Kilamuwa of Sam'al (c. 840/830 BC) wearing a bracelet with a rosette disc shown on the inside of his left wrist (right wrist damaged) ${ }^{11}$ whereas Barrakib of Sam'al (c. $730 \mathrm{BC}$ ) wears none, ${ }^{12}$ although a woman, perhaps his queen, wears a bracelet with two visible rosette discs on her raised right wrist, and a four-banded bracelet on her left wrist. ${ }^{13}$

This brings us to representations of the "Royal bracelet" which, potentially, can be divided into three types.

a) With one disc (e.g. Figs. $4 b-c, 5$ ). Here the rosette is shown on the outside of one wrist, with the band on the inside of the other wrist. This is how a bracelet of Pairs 1 and 2 would have appeared if correctly represented in what is referred to here as "true perspective".

b) With two discs (e.g. Fig. 4a). Here a disc is shown on the wrist closest to the viewer, and on the inside of the other wrist. This could be understood as the depiction of a bracelet consisting of two discs, but it seems more likely that it is a convention to show that both bracelets consisted of one disc. This seems to be confirmed by the few extant sculptures in the round of Assyrian kings. ${ }^{14}$

c) With three discs (e.g. Fig. 6). This is the type of bracelet represented by Pair 3 .

\section{Chronological development of the bracelets}

Although Tukulti-Ninurta I (1243-1207 BC) is shown wearing bracelets, these are plain. ${ }^{15}$ Thus probably the earliest, and certainly the most numerous depictions of the "Royal bracelet" belong to the reign of Assurnasirpal II ( $883-859 \mathrm{BC}$ ) when this form of insignia may originally have been

\footnotetext{
${ }^{8}$ For exceptions with only one bracelet, see Paley and Sobolewski 1992, Pl. 4, E.c.1, ED.2 and ED.9.

${ }^{9}$ Niederreiter 2008, passim.

${ }^{10}$ E.g. Magen 1986: Babylon, Pl. 22: 3-6; Iran, Pl. 23: 1-2 (?), and Teumann at Til Tuba (Barnett et al. 1998, Pl. 294, Top 382b (detail)).

${ }^{11}$ Magen 1986, PI. 21: 1.
}

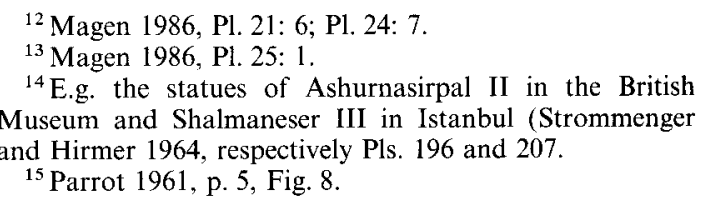


developed (Fig. $4 a-c$ ). Both Type $a$ and Type $b$ occur on the reliefs, stelae and statues from the temples and especially the North-West Palace at Nimrud, but as the variations are generally related to the decoration of specific rooms, it seems that, with few exceptions (Rooms B, H and $\mathrm{S}$ where both types occur), different teams of workmen used different templates. This reinforces the suggestion that Types $a$ and $b$ probably depicted "Royal bracelets" with a single disc, with only Type $a$ being shown in "true perspective". ${ }^{16}$ Type $a$, found in Rooms B, F, H, S, perhaps T, $\mathrm{Z}$ and WFL, is worn by the king and winged human-headed minor deities. Type $b$ occurs in Rooms B, G, H, L, S and perhaps T, worn by the king, winged human-headed minor deities, eagle-headed genii, and worn by a courtier in Room $S$ (see note 6).

There is scant pictorial evidence for the next few reigns. The "Royal bracelet", probably in "true perspective" (i.e. of Type $a$ ) is depicted on statues of Shalmaneser III (858-824 BC) (Strommenger 1964, Pl. 207; Magen 1986, Pl. 6:4 but Pl. 6:5 may be a forgery), on the glazed panel from Fort Shalmaneser (Magen 1986, Pl. 8:4), and on the Black Obelisk (Börker-Klähn 1982, No. 152A1-2). However, the Kurkh Monoliths are too worn, and the scale of the Balawat Gates is too small to be of use in this respect. "Royal bracelets" in "true perspective" are also depicted on the well-preserved stele of Shamshi-Adad V (823-811 BC) (Fig. 5), and on that of Adad-nirari III (810-783 BC) from Tell al-Rimah (Magen 1986, Pl. 8: 6-7).

For the reigns of Tiglath-pileser III (744-727 BC) and Shalmaneser V (726-722 BC) the evidence is varied. The best publication of the Neo-Assyrian wall-paintings from the provincial capital at Til-Barsip in north Syria (Parrot 1961, Figs. 110-13), shows the coloured reconstructions of some of the fragmentary paintings, with the enthroned king appearing on Figs. 112 and 113 where he is shown wearing pairs of bracelets, as is a high official or crown-prince. ${ }^{17}$ On Fig. 110, an apotropaic figure wears a rosette bracelet on his left wrist (the one nearest the viewer), but no trace survives on the other wrist. An examination of the evidence in Barnett and Falkner 1962 relies to a large degree on drawings of reliefs that have not survived, so preference has been given here to examples where the relief is extant and the accuracy of the drawings can be checked. The discs are generally much smaller than in previous reigns. ${ }^{18}$ However, on a piece cut from a larger relief ( $\mathrm{Pl}$. XCVIII = BM 118900), the king wears a large rosette on the one preserved wrist. A small bracelet is worn by a courtier on Pl. CI, and by an apotropaic figure on Pl. CV. Frequently the king does not wear a "Royal bracelet", even where it would be expected (Fig. 6a). ${ }^{19}$

It seems, therefore, that during much of the eighth century BC the "Royal bracelet" no longer retained the importance and exclusivity it had once enjoyed. A further indication of this is provided by the stele of Bēl-harran-bēli-usur (Fig. 6b). This official described himself as the "palace herald of Tiglath-pileser [III]" and indeed his skirt has the checked pattern which is typical of that reign. The fact the Bèl-harran-belli-usur wears the "Royal bracelet", as well as a huge rosette on his chest, can be added to the numerous "factors [that] indicate the extent of his independence from the king of Assyria" (Grayson 1996, p. 241-2). However, the name of the king had replaced the erased name "Shalmaneser" - the fourth king of that name according to Grayson, but Reade

\footnotetext{
${ }^{16}$ The main sources are Paley 1976, where the reliefs are illustrated by large, clear photographs, whereas Meuzyński 1981, and Paley and Sobolewski 1987, both have schematic drawings of the sequences of reliefs, which are often too small for details to be clear, and the lower wrist is frequently covered by lines of Ashurnasirpal's Standard Inscription. For this reason the attribution to Types $a$ or $b$ is not necessarily reliable: for instance in Meuzyński 1981, and Paley and Sobolewski 1987, Type $a$ was indicated on F-12, whereas Type $b$ was shown on F-14, and F-13 depicted the backs of the bracelets twice, but there was no publication of the actual reliefs. On L-10, Types $a$ and $b$ face each other (see Stearns 1961, P1. 17 from Kansas, plus Stearns 1961, Pl. 31 from Hanover and Dartmouth, as suggested in Reade 1965, pp. 133 f.; and see Meuzyński 1981, p. 67). Either craftsmen from different teams were working together, using different templates, or the information on which the sketches were based was unclear.

${ }^{17}$ The details are not clear, but a rosette is shown on the inside of the king's left wrist on Fig. 112, implying either
}

that "true perspective" was not adopted by the original painter, or that the modern reconstruction relied on earlier reliefs. On Fig. 113 the enthroned king wears a bracelet on the wrist nearest the viewer, but the other wrist is damaged, and on both, the crown-prince faces him, also wearing rosette bracelets, but again it seems that "true perspective" was not adhered to. Note that some of the wall paintings are later than Tiglath-pileser III.

${ }^{18}$ For instance on Pls. XVIII-XIX - worn by enthroned king receiving prisoners. On Pls. LXXXIV-LXXXV (in Detroit) the king and courtiers wear small bracelets, but the crown-prince wears a larger one, and all are depicted according to "true perspective".

${ }^{19}$ For instance on Pl. LIX no bracelets are worn either by the enthroned king receiving prisoners, or, on PI. LXXI, by the victorious king in his chariot at Astartu (see Fig. $6 a$ ). On Pl. VIII a bracelet is worn by the crown-prince, but not by the king, and on Pls. XXIII-XXIV a bracelet with the rosette visible on both wrists is worn by a courtier or official who introduces prisoners. 

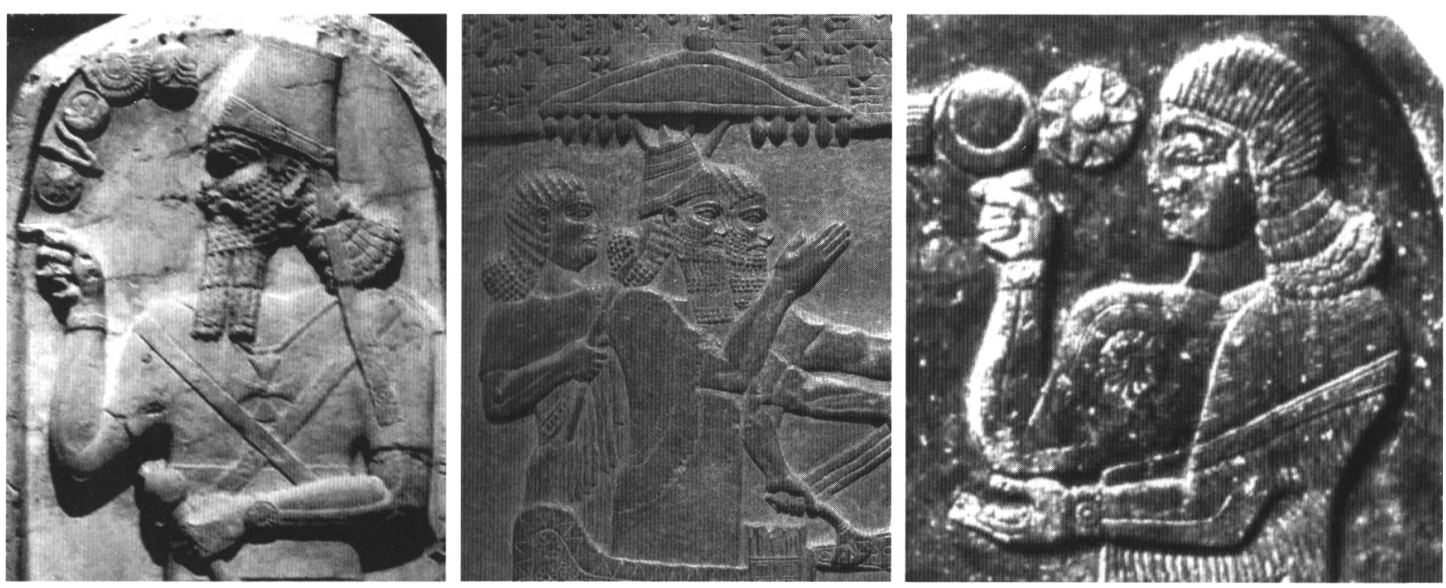

Fig. 5 Stele of Shamshi-Adad V, from the Nabu Temple at Nimrud c. 814 BC (detail of BM 118892).

Fig. $6 a$ Tiglath-pileser III at Astartu, from the South-West Palace at Nimrud c. 730-727 BC (detail of BM 118908).

Fig. $6 b$ Detail of the stele of Bēl-harran-bēli-usur from Tell Abta in northern Iraq (Istanbul Museum no. 1326)

(1981, p. 160) has argued that this would have been Shalmaneser V, and that Bēl-harran-bèli-usur ordered the alteration so as to find favour with Sargon II when the latter came to the throne.

Type $c$, with three discs, is first worn by Sargon II (726-722 BC) and by a high official on reliefs from Khorsabad (Fig. 7; Albenda 1986, Pls. 44, 45, Figs. 61 and 67, but not Pl. 70), but the discs are on a horizontally-ridged bangle. There seems to have been a reaction to the paucity of bracelets in the previous reign, and there is now a greater variety of bracelets, and particularly of "rosette" bracelets, than there ever had been (see Albenda 1986, Pl. 139). Types $a$ and $b$ also occur (see the minor winged deities and apotropaic figures in Albenda 1986, respectively Figs. 9, 16 and 17, and 10 ), with Type $a$ by far the most popular.

Under Sennacherib (704-681 BC) the bracelets worn by the king are mostly damaged due to the poor state of preservation of the stone, but they seem to show a single disc. In the case of the relief sequence showing the fall of the Judaean city of Lachish, depicted in Room XXXVI of Sennacherib's South-West Palace at Nineveh, it may be that the deliberate damage inflicted on the king's image not only included his face (Fig. 8) but also the bracelets he probably once wore. Indeed, both his wrists were smashed and have had to be repaired. This might be evidence that the protective nature of "Royal bracelets" was understood by those who sacked the palace at the time of the fall of Nineveh in $612 \mathrm{BC}$; it should be noted that the bracelet worn by the crown-
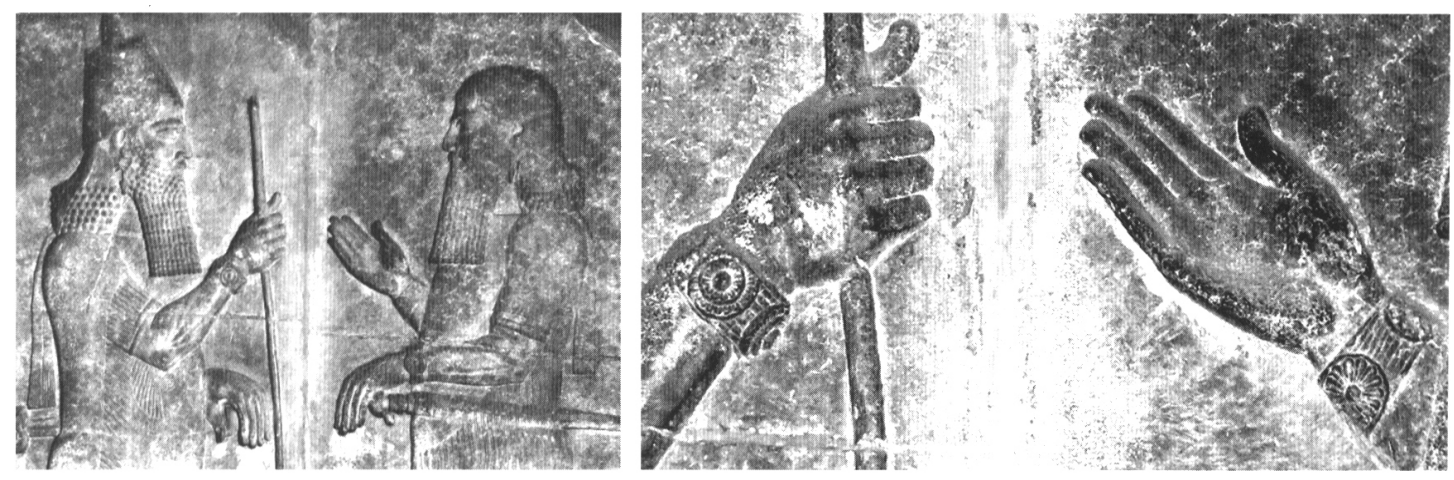

Fig. $7 a-b$ Details of a relief from the palace of Sargon II at Khorsabad, showing Sargon, on the left, with the crown prince, c. 710-705 BC (BM 118822). 


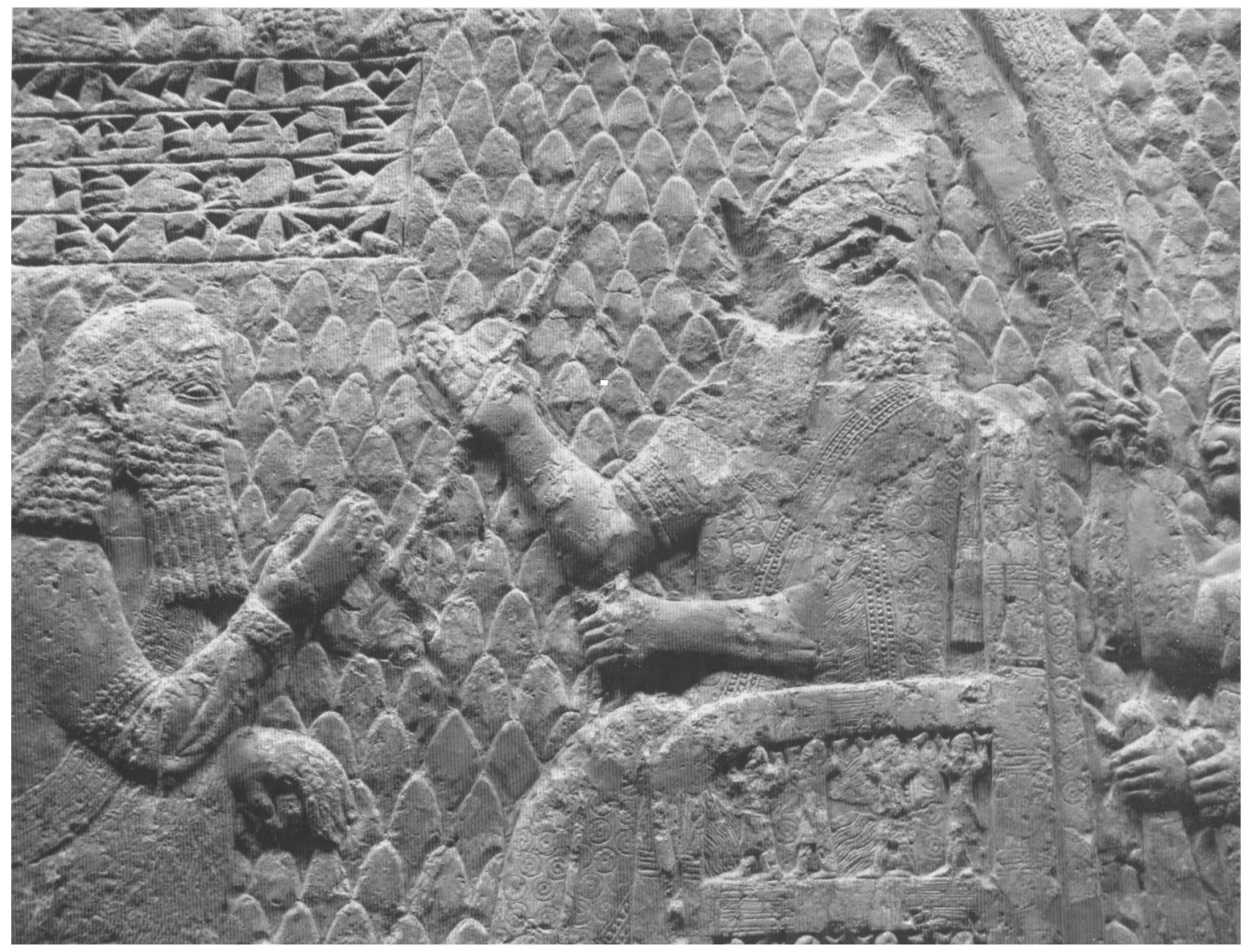

Fig. 8 Detail of a relief from Room XXXVI in Sennacherib's South-West Palace at Nineveh, c. 700-692 BC: Sennacherib at Lachish, showing modern repair to his damaged wrists (BM 124911).

prince facing him is still intact. ${ }^{20}$ Type $c$ reappears under Sargon's grandson, Esarhaddon (680-669 BC), who wears bracelets with triple discs on the Sam'al stele. On the sides of the stele his Babylonian and Assyrian heirs are depicted wearing similar bracelets (Fig. 9; after BörkerKlähn 1982, No. 219; see also Porter 2003, Pls. 28-9).

Ashurbanipal (668-627 BC) also reverts to bracelet types found under Sargon, sometimes with three discs applied to broad bracelets (see Figs. 10 and 12, worn by the king, queen and attendants, and cf. Fig. 7), and with lions' heads flanking a single disc (Albenda 1986, Fig. 66 and cf. Fig. 10, upper left). Other bracelets (and often armlets) are elaborate, they only seem to have one disc, and when the king is hunting and wears a wrist guard, the bracelet is generally replaced on that arm by an ostentatious armlet (Fig 10; see also Strommenger and Hirmer 1964, Pls. 251, 254, 258 and 261).

In conclusion, it would seem probable that Pair 3, the three-disc bracelet deposited in Tomb II, should belong to the reign of Sargon, since this is when the type is first attested and, indeed, inscriptions found in the tomb tell us that Atalia was his queen. However, instead of the three discs being adjacent (as on Pair 3), they seem to be mounted on a horizontally-ridged bangle.

Pair 2 may also date to Sargon's reign since a lion was incised on the interior of one bracelet, and a pair of lions inside the other. Niederreiter (2008, pp. 56-7 and 76-9) has shown that this symbolic Neo-Assyrian association of the lion with royalty dates back to Ashurnasirpal II, but

\footnotetext{
${ }^{20}$ In support of this proposal are the facts that this part of the relief is not fire-damaged and cracked, and the surface is otherwise well preserved. Furthermore, in order to aid reconstruction of the fragments, detailed numbered drawings were made of the reliefs of Room XXXVI before they were packed for shipping to England in the mid-nineteenth
}

century (see Barnett et al. 1998, No. 435b), and a close study of Original Drawings Vol. II: 8 , in the archives of the Department of the Middle East in the BM, shows that the damage to the king's wrists had been recorded by fine hatched lines. 

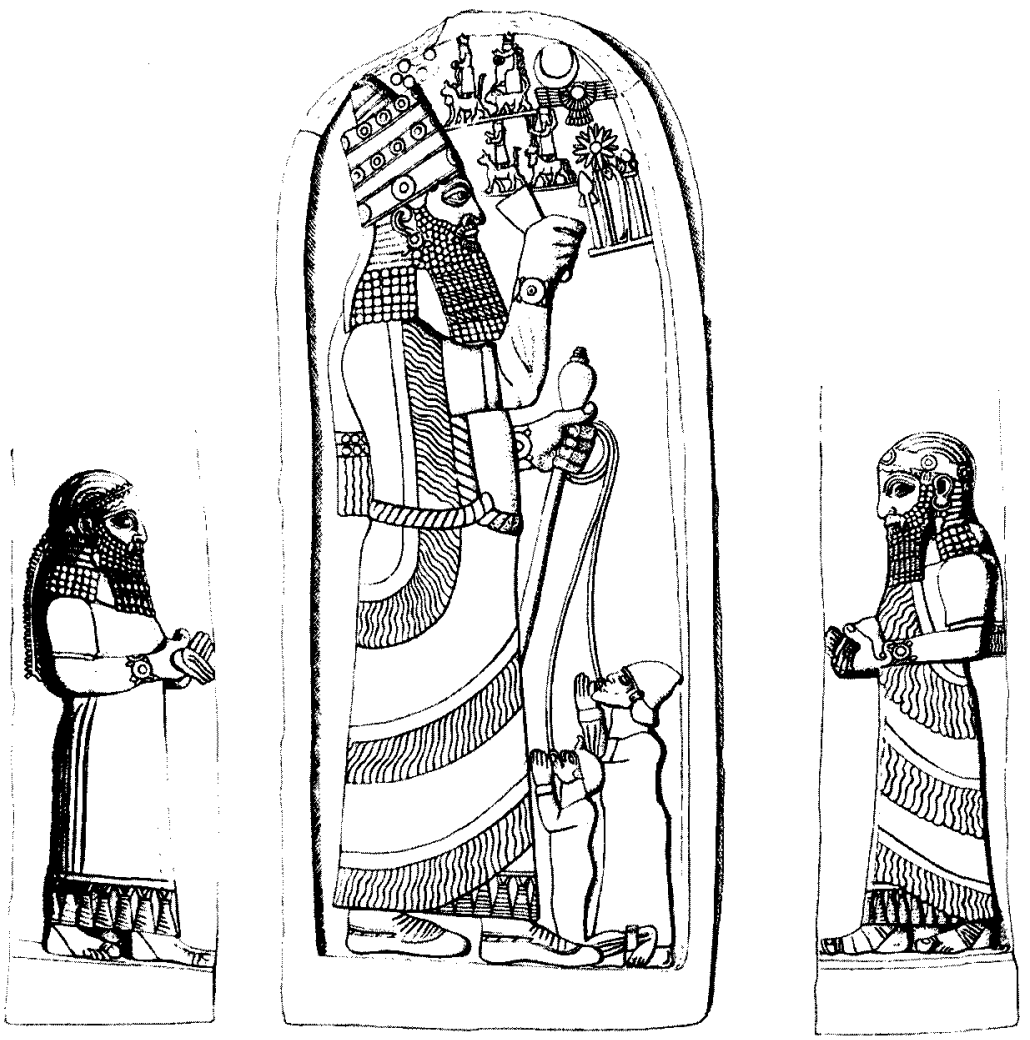

Fig. 9 Front and sides of Esarhaddon's stele from Sam'al (Berlin).

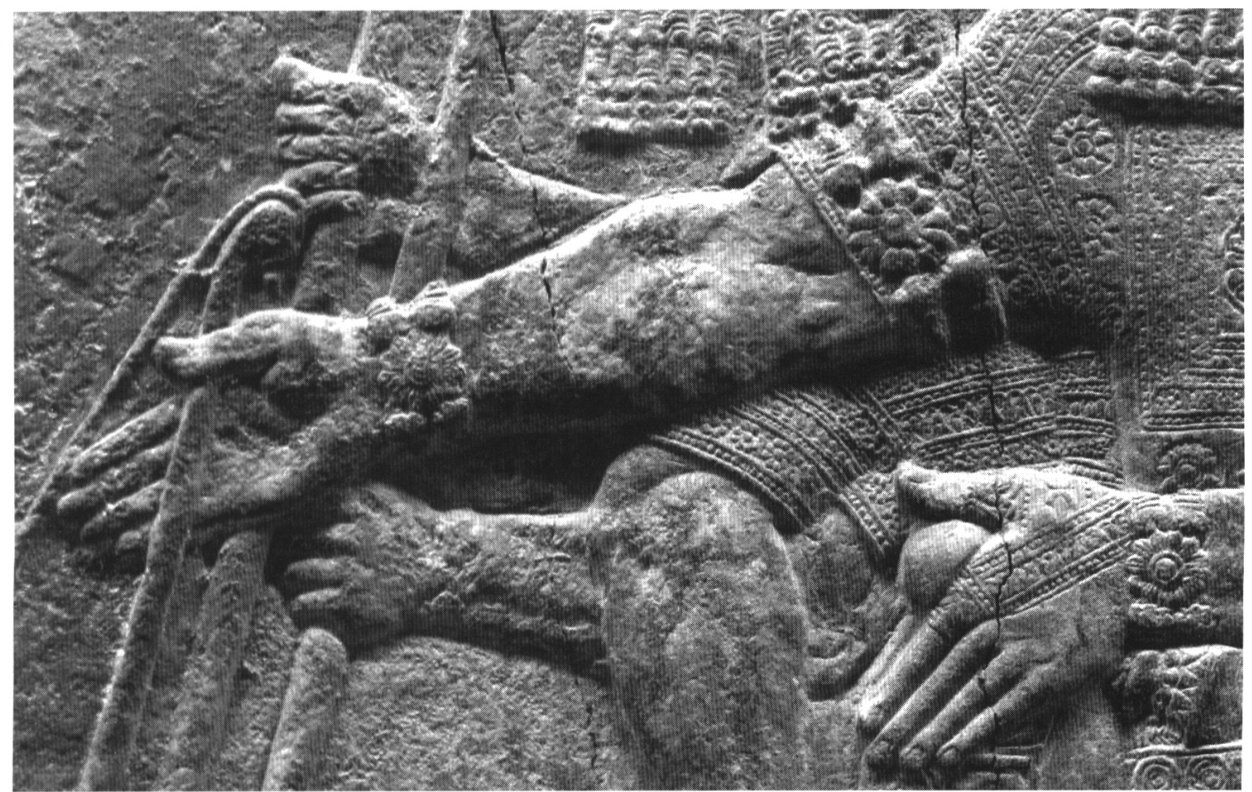

Fig. 10 Ashurbanipal receiving a bow before the lion hunt: relief from his North Palace at Nineveh, c. 645 BC (detail of BM 124858).

was particularly developed under Sargon; however, he omits reference to these incised lions in his long lists of occurrences. In Sargon's reign cryptographic writing was used on glazed bricks, a tradition that continued under Esarhaddon (Niederreiter 2008, pp. 79-81). High-ranking officials in Sargon's court also used cryptographic symbols for writing their names (Niederreiter 2008, 


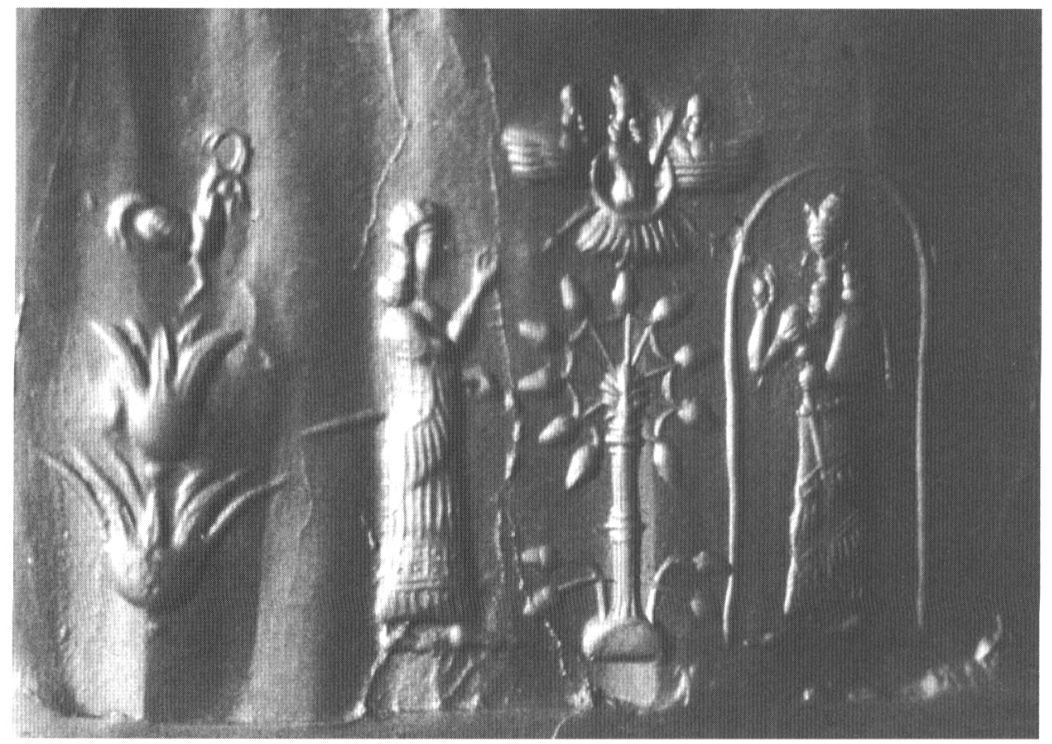

Fig. 11 Cylinder seal from a foundation deposit in Sennacherib's South-West Palace at Nineveh (BM 89502).

pp. 65-9). Many objects from Tomb II were marked with symbols, especially the scorpion that was associated with the harem (Niederreiter 2008, pp. 59-62, 82). Indeed, a group of objects excavated by Layard, perhaps a foundation deposit, was "connected with the bulls forming the grand entrance" of Sennacherib's South-West Palace at Nineveh, and included not only a lapislazuli scorpion, but a pale-green chalcedony cylinder seal (Fig. 11; Collon 2001, No. 173) which depicts a king in an attitude of worship before a royal stele. Some of the symbols on the seal could be read as a cryptographic inscription naming one of Sargon's officials, Ashur-nadin-ahhe, ${ }^{21}$ alongside a Babylonian "rosette tree" - precisely the type of tree depicted on Pairs 1 and 2 . The winged disc above the tree includes a god emerging from the winged disc, and the heads of two gods on the wings - probably acolytes of the sun god.

\section{The bracelets from Tomb II at Nimrud}

As we have seen, the bracelets from Tomb II were found in a sarcophagus containing the bodies of two women, but the vast majority of bracelets depicted on Neo-Assyrian reliefs are worn by kings. Indeed, very few high-class women appear on the reliefs, but Reade (1987) has demonstrated the importance of royal women during the reigns of Sennacherib, Esarhaddon, ${ }^{22}$ and Ashurbanipal (Figs. $12 a$ from Börker-Klähn 1982, Fig. 227, and 12b). However, Ashurbanipal postdates Tomb II by almost a century.

It is striking that the majority of the bracelets illustrated in official Assyrian art seem to have designs based on a rosette. However, this is not the case with the three pairs from Tomb II, all of which have in common a design consisting of winged apotropaic figures kneeling on one knee, flanking a rosette-tree or disc. This very Assyrian motif decorated Room I in the North-West Palace of Ashurnasirpal at Nimrud, where the figures kneel with hands extended on either side of typically-Assyrian stylised trees (Fig. 13a). Kneeling figures are also depicted on wall paintings from Room XXV of the palace at Til Barsip (Magen 1986, Pl. XXV:4), and from the palace of Sargon II at Khorsabad (Fig. $13 b$ from Parrot 1961, p. 266, Fig. 342) where they appear with cone and bucket, as on the bracelets, and flank rosettes similar to those that characterise more

\footnotetext{
${ }^{21}$ I should like to thank Irving Finkel for this suggestion. See also Reade 1995, pp. 231, esp. 236, 245 Fig. 8.

${ }^{22}$ It has been suggested that the goddess on a rock-relief at Bavian may be depicted in the guise of Sennacherib's queen (see Reade 1987), and she does indeed wear bracelets with multiple rosettes on each wrist (Börker-Klähn
}

1982, Fig. $187 a-b$ ). A bronze plaque in the Louvre shows Sennacherib's wife, Naqia, following her son Esarhaddon, but the edges of her long sleeves and cracks in the bronze obscure any bracelet she might have worn (Parrot 1961, p. 118, Fig. 133 = Magen 1986, Pl. 11:5). 

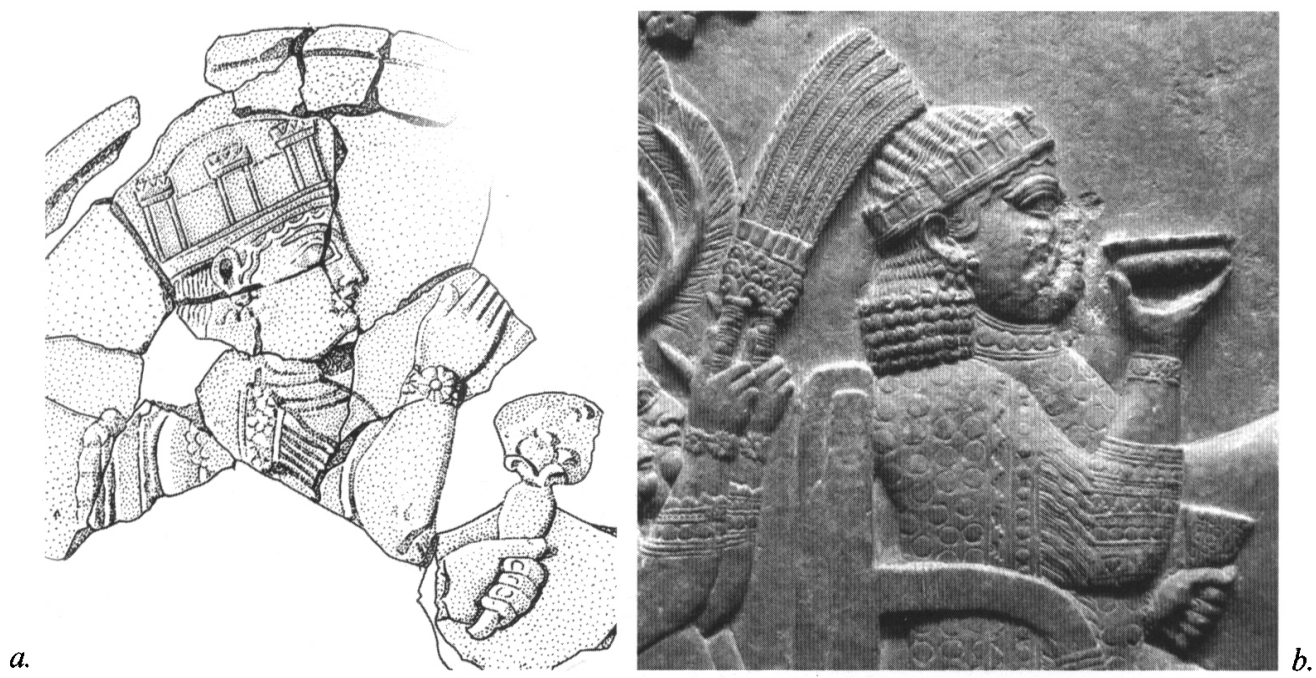

Fig. 12 Libbali-sharrat, Queen of Ashurbanipal, c. 645-635 вC.

a. Upper part of her fragmentary stele from the Stelenreihen at Assur.

$b$. Detail from the "Garden Party" relief from Ashurbanipal's North Palace at Nineveh (BM 124920).
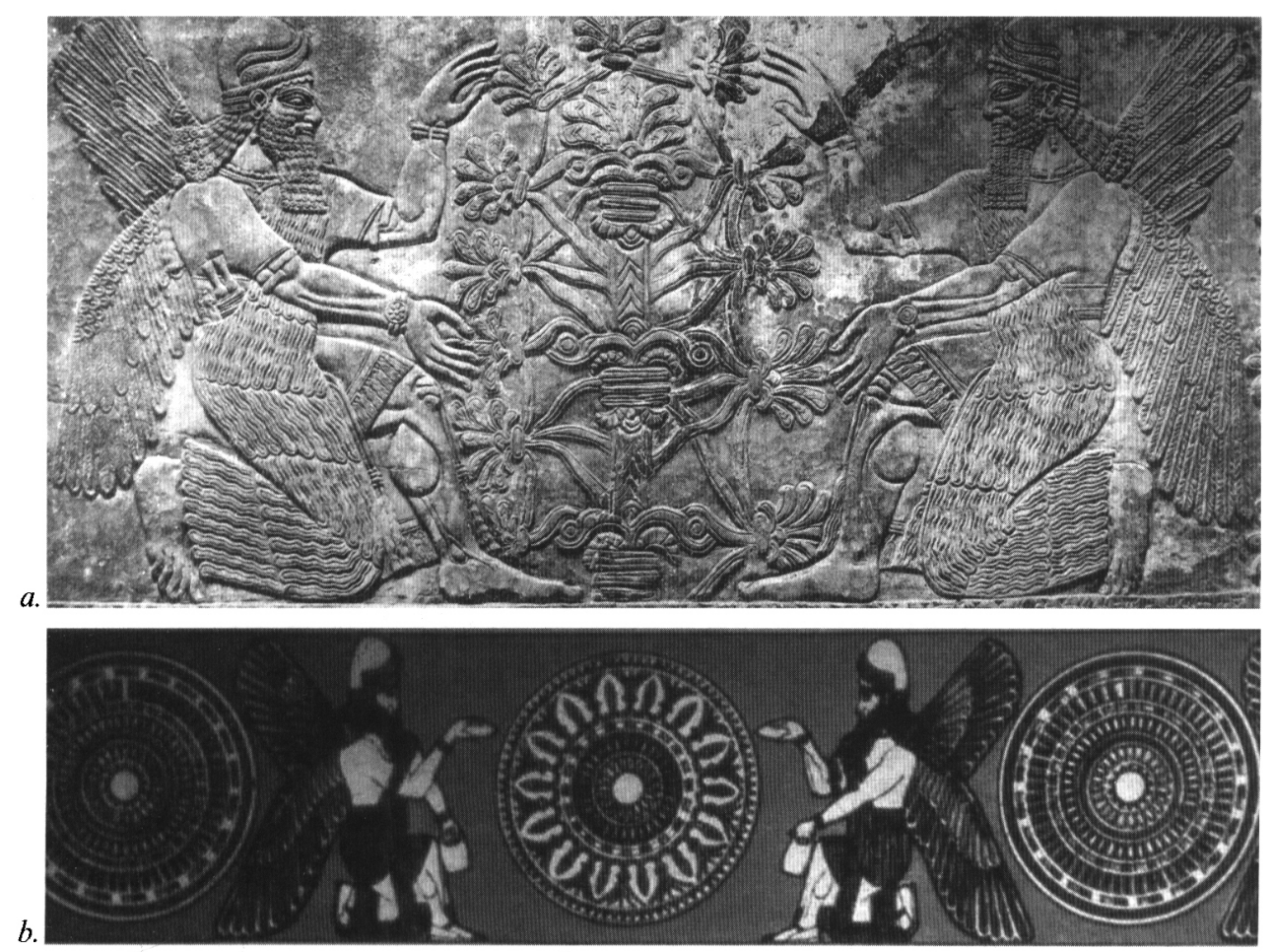

rig. 12 wingeu gous llanking a slyilsed piant.

a. From Ashurnasirpal's North-West Palace at Nimrud, Room I, c. 865-860 BC (BM 124580).

$b$. Painted decoration from the palace of Sargon II at Khorsabad, c. 710-705 BC.

Babylonian trees (see Collon 2001, pp. 84-5). On the bracelets of Pairs 1 and 2, and on the side discs of Pair 3, the bands with these kneeling figures surround a central rosette. On Pair 3, however, the band on the central disc surrounds an extraordinary motif.

This central motif is only half the size of the central disc, and must therefore measure about $2.65 \mathrm{~cm}$ in diameter, including the border (Fig. 14). It seems at first glance to be a routine image of two robed and bearded figures facing each other, with divine symbols between them. The scale 

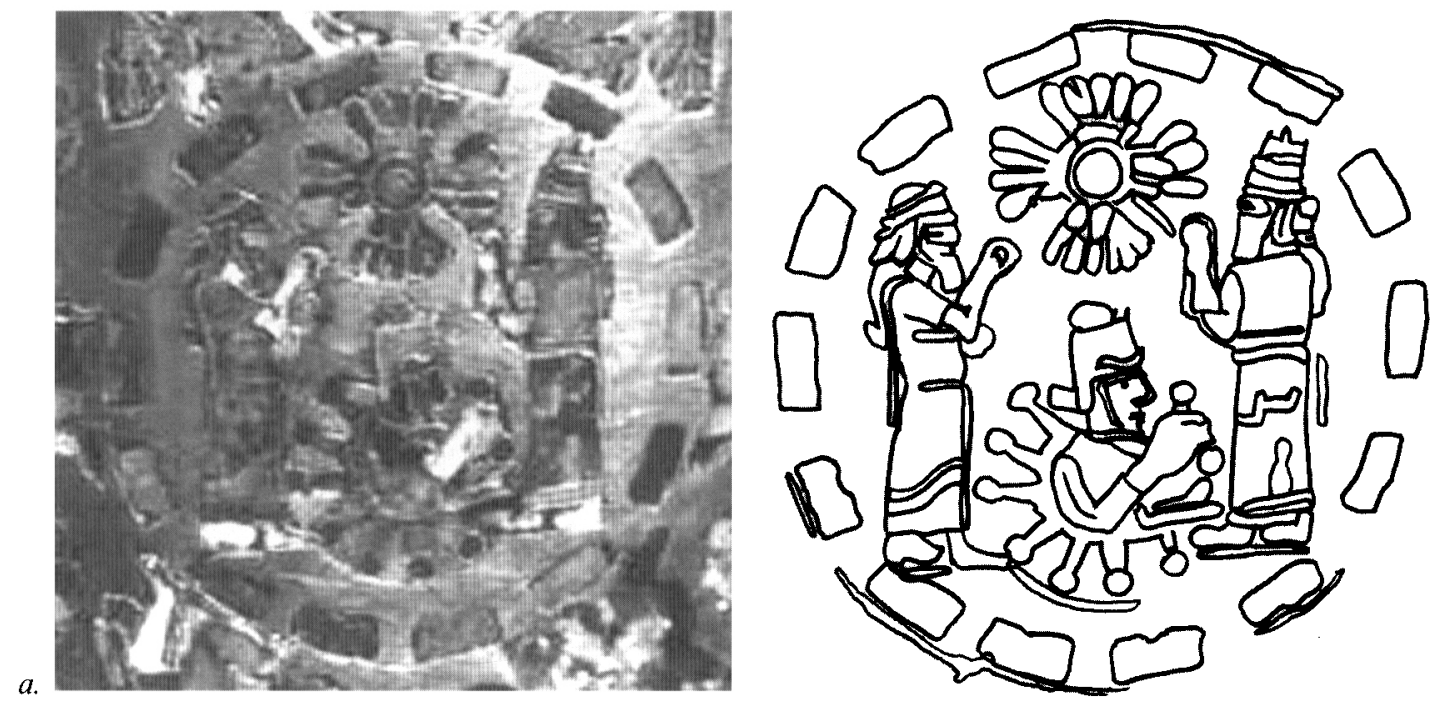

$b$.

Fig. 14a-b Central motif on the Damerji Pair 3 bracelet.

of this image on the available photographs is such that the identity of the figures is not easy to establish. However, the figure on the right is clearly the more important: he is much larger, and wears a tall fez banded in different colours, with a diadem or upturned brim, topped by a cone, with ribbons down the back. This, according to Reade, is typical of the fez worn by Sargon and later kings (Reade 2009, pp. 255). The figure wears a bordered robe that is draped over his shoulder and encloses his left arm, and he raises his right hand. All this is typical of depictions of Assyrian kings standing before deities or their symbols (Magen 1986, Type III b-2, Pls. 7: 6-11, 8 and 9, and pp. 92-108). The figure facing the king wears a headband that is broader in front, with ribbons down the back, and his robe is less elaborate; he also raises his right hand. ${ }^{23} \mathrm{His}$ head-band may identify him as the crown-prince, who is often depicted facing the king (e.g. on Figs. 7 and 8 ).

Between the figures, the upper motif consists of a cross formed by the tails of four birds. It recalls the elaborate winged disc found on several ivories from Nimrud, including the lion bowl from Well AJ at Nimrud, referred to above in connection with the lions' heads forming the back of the bracelet (Herrmann 2009, Fig. 38), but especially on two ivories from Fort Shalmaneser (Mallowan and Herrmann 1974, Pl. XLIV: Nos. 26-7, and Pls. XXXII-XXXIII: No. 21 = Parayre 1989 , p. 48 Figs. 3-4), where the winged discs resemble crosses consisting of four groups of feathers and two prominent volutes - the latter perhaps omitted on the bracelet due to the very small scale of this detail. Parayre (1989) has grouped a number of objects with related winged dises, many of them on seals belonging to the so-called Yunus Group centred on Carchemish and dated to the late eighth century BC (Boardman and Morey 1986; Boardman 1996).

The motif below is described in the Catalogue as "a stone bench", but it is, in fact, a circle of dot-tipped rays that surrounds a disc from which rises the bust of a deity who faces right, wears a cylindrical, globe-topped, horned headdress and raises his right hand. This is clear on the image published by Damerji (Abb. 30 top). On the pair of the Damerji bracelet, illustrated in the Catalogue (Cat. Pic. 31), the image is not at all clear, but the deity might be facing left instead of right.

It seems, therefore, that the main figures in the central disc of the bracelet illustrated by Damerji are the crown prince facing a king who stands in a position of worship before the symbols of the gods. Whether or not the cross of four tails is related to a type of winged disc from the Carchemish region in the late eighth century $\mathrm{BC}$, it clearly replaces the winged disc that generally appears in

\footnotetext{
${ }^{23}$ It appears as though this figure could be holding the ring that deities normally hold, but it is more likely that his
}

inlaid hand is chipped and the "ring" is actually the gold strip that once held the inlay in position. 
such a context. ${ }^{24}$ On seals, the disc is generally outlined, whereas on reliefs it is often a rosette. However, on both seals and reliefs the upper part of a deity with one hand raised appears frequently (see Collon 2001, pp. 80-1). There is some debate as to whether the deity is the national god Assur, or the sun god Shamash, as is the case on Fig. $11 .^{25}$

\section{Conclusion}

The central motif on the third pair of bracelets is small, but it is shocking. The winged disc is reduced to the tails of four birds and, even more shocking, the god in the disc is not dominating the scene, but is level with the feet of the crown-prince and king. Whoever made these two bracelets, it seems unlikely that they were Assyrians. Maybe the bracelets were the work of jewellers uprooted from their homeland and forced to exercise their trade in an alien court and for alien masters. More specifically, could they have been part of the political "dowry" of one of the Levantine "queens" in whose tomb the bracelets were found? Indeed, the names of the two women seem to be Levantine (Dalley 2008). Were the jewellers unaware of the strict conventions governing Assyrian art? Or were they expressing their resentment and independence by embedding in their work a small and inauspicious message of revolt? Was anyone else aware of the message carried by the design on the Pair 3 bracelets? Did no-one notice the implied blasphemy in this miniature depiction?

Purposefully or through ignorance, someone in Assyria had got the iconography terribly wrong. ${ }^{26}$

\section{Bibliography}

Albenda, P. 1986: The Palace of Sargon King of Assyria / Le palais de Sargon d'Assyrie (Éditions Recherche sur les Civilisations, "Synthèse" no. 22), Paris.

Al-Rawi, F. 2008: "Inscriptions from the tombs of the queens of Assyria" in Curtis et al. 2008, pp. 119-38.

Barnett, R. D. and Falkner, M. 1962: The Sculptures of Ašsur-nasir-apli (883-859 B.C.), Tiglath-pileser III ( $745-727$ B.C.). Esarhaddon (681-669 B.C.) from the Central and South-West Palaces at Nimrud, London.

Barnett, R. D., Bleibtreu, E. and Turner, G. 1998: Sculptures from the Southwest Palace of Sennacherib at Nineveh, London.

Boardman, J. and Moorey, P. R. S. 1986. "The Yunus Cemetery group: haematite scarabs", In M. KellyBuccelati (ed.), Insight through Images: Studies in Honor of Edith Porada (Bibliotheca Mesopotamica 21), Malibu, 35-48.

Boardman, J. 1996. "Some Syrian glyptic", Oxford Journal of Archaeology 15, 327-40.

Börker-Klähn, J. 1982: Altvorderasiatische Bildstelen und vergleichbare Felsreliefs (Baghdader Foschungen 4), Mainz.

Budge, E. A. W. 1914: Assyrian Sculpture in the British Museum, Reign of Ashur-Nasir-Pal, 885-860 B.C., London.

Collon, D. 2001: Catalogue of the Western Asiatic Seals in the British Museum, Cylinder Seals V. Neo-Assyrian and Neo-Babylonian Periods, London.

Curtis, J. E., McCall, H., Collon, D. and al-Gailani Werr, L. (eds.) 2008, New Light on Nimrud - Proceedings of the Nimrud Conference $11^{\text {th }}-13^{\text {th }}$ March 2002, London.

Dalley, S. 2008: "The identity of the princesses in Tomb II and a new analysis of events in 701 BC", in Curtis et al. 2008, pp. 171-5.

Damerji, M. S. B. 1999: "Gräber assyrischer Königinnen aus Nimrud", Jahrbuch des römisch-germanischen Zentralmuseums 45, Mainz.

Grayson, A. K. 1996: Assyrian Rulers of the Early First Millennium BC II. ( $858-745$ BC) (Royal Inscriptions of Mesopotamia Assyrian Periods Vol. 3), Toronto.

Herrmann, G. and Laidlaw, L. 2009: Ivories from the North West Palace (1845-1992) (Ivories from Nimrud VI), London.

Hussein, M. M. and Suleiman, A. 2000: Nimrud - A City of Golden Treasures, Baghdad.

Madhloom, T. A. 1970: The Chronology of Neo-Assyrian Art, London.

\footnotetext{
${ }^{24}$ Magen 1986, Pls. 8:7, 14:4, 7; Collon 2001, Nos. 151, $161-3,173$.

${ }^{25}$ For a discussion and illustrations of the motif on seals, see Collon 2001, pp. 79-82.

${ }^{26}$ Julian Reade does not believe in the conspiracy theory as too many different specialists, designers and jewellers would have been involved. He has suggested that the order
}

of the motifs was confused and the god should have been placed at the top, and the "wings" below. He may well be right, but even if the "wings" were intended to be placed at the feet of the figures, the rules would still have been violated. This violation involved not only the cutting out of the gold sockets, but also the shaping and positioning of the inlays - not on one, but on two bracelets! 
Magen, U. 1986: Assyrische Königsdarstellungen — Aspekte der Herrschaft, eine Typologie (Baghdader Forschungen 9), Mainz.

Mallowan, M. E. L. and Herrmann, G. 1974: Furniture from SW7 Fort Shalmaneser (Ivories from Nimrud III), London.

Medvedskaya, I. 1988: "Who destroyed Hasanlu IV?" Iran 26, pp. 1-15.

Meuszyński, J. 1981: Die Rekonstruktion der Reliefdarstellungen und ihrer Anordnung im Nordwestpalast von Kalhu (Nimrud) Räume: B.C.D.E.F.G.H.L.N.P. (Baghdader Forschungen 2), Mainz.

Niederreiter, Z. 2008: "Le rôle des symboles figurés attribués aux membres de la cour de Sargon II: Des emblèmes créés par les lettrés du palais au service de l'idéologie royale", Iraq 70, pp. 51-86.

Oates, J. and Oates, D. 2001: Nimrud - An Assyrian Imperial City Revealed, London (British School of Archaeology in Iraq).

Paley, S. M. 1976: King of the World - Ashur-nasir-pal II of Assyria 883-859 B.C., The Brooklyn Museum.

Paley, S. M. and Sobolwski, R. P. 1987: The Reconstruction of the Relief Representations and their Positions in the Northwest-Palace at Kalhu (Nimrud) II. (Rooms: I.S.T.Z, West-Wing) (Baghdader Forschungen 10), Mainz.

Parayre, D. 1989: "A propos d'une plaque de harnais en bronze découverte à Samos : Réflexions sur le disque solaire ailé", Revue d'Assyriologie 83, pp. 45-51.

Parrot, A. 1961: Nineveh and Babylon, London.

Porter, B. N. 2003: Trees, Kings, and Politics - Studies in Assyrian Iconography (Orbis Biblicus et Orientalis 197), Fribourg and Göttingen.

Reade, J. E. 1965: “Twelve Ashur-nasir-pal reliefs", Iraq 27, pp. 119-35.

Reade, J. E. 1981: "Neo-Assyrian monuments in their historical contexts", in F. M. Fales (ed.), Assyrian Royal Inscriptions: New Horizons in Literary, Ideological, and Historical Analysis. Papers of a Symposium held in Cetona (Siena) June 16-28, 1980 (Orientis Antiqui Collectio XXVII). Published by the Istituto per l'Oriente, Centro per le Antichità e la Storia dell' Arte del Vicino Oriente, Rome.

Reade, J. 1987: "Was Sennacherib a feminist?", in La femme dans le Proche-Orient Antique. (Editions Recherches sur les Civilisations), Paris, pp. 139-45.

Reade, J. 1995: "The Khorsabad glazed bricks and their symbolism", in A. Caubet (ed.), Korsabad: Le palais de Sargon II roi d'Assyrie. Actes du colloque organisé au Musée du Louvre par le service culturel les 21 et 22 janvier 1994, Paris, pp. 225-51.

Reade, J. 2009: "Fez, diadem, turban, chaplet: Power-dressing at the Assyrian court", in M. Luukko, S. Svärd and R. Mattila (eds.), Of God(s), Trees, Kings, and Scholars - Neo-Assyrian and Related Studies in Honour of Simo Parpola (Studia Orientalia 106), Helsinki, pp. 239-64.

Russell, J. M. 2008: "Thoughts on room function in the North-West Palace", in Curtis et al., 2008, pp. $181-93$. Stearns, J. B. 1961: Reliefs from the Palace of Ashurnasirpal II (Archiv für Orientforschung, Beiheft 15), Graz. Strommenger, E. and Hirmer, M. 1964: The Art of Mesopotamia, London.

Dr Dominique Collon

c/o Department of the Middle East

The British Museum

London WC1B 3DG 